\title{
Assessment of ammonia and greenhouse gas emissions from broiler houses in Portugal
}

\author{
José L.S. Pereira ${ }^{a, b, *}$ \\ ${ }^{a}$ Polytechnic Institute of Viseu, Agrarian School of Viseu, CI\&DETS, Quinta da Alagoa, 3500-606 Viseu, Portugal \\ ${ }^{\mathrm{b}}$ University of Trás-os-Montes and Alto Douro, CITAB, Quinta de Prados, 5000-801 Vila Real, Portugal
}

\section{A R T I C L E I N F O}

\section{Article history:}

Received 8 January 2017

Received in revised form

29 March 2017

Accepted 30 March 2017

Available online 4 April 2017

\section{Keywords:}

Broiler husbandry

$\mathrm{CH}_{4}$

$\mathrm{CO}_{2}$

$\mathrm{NH}_{3}$

$\mathrm{N}_{2} \mathrm{O}$

Southern Europe

Winter

\begin{abstract}
A B S T R A C T
Broiler husbandry is a significant source of ammonia $\left(\mathrm{NH}_{3}\right)$, nitrous oxide $\left(\mathrm{N}_{2} \mathrm{O}\right)$, carbon dioxide $\left(\mathrm{CO}_{2}\right)$ and methane $\left(\mathrm{CH}_{4}\right)$ emissions but scarce studies have been made under Mediterranean conditions. The aim of this study was to evaluate the $\mathrm{NH}_{3}, \mathrm{~N}_{2} \mathrm{O}, \mathrm{CO}_{2}$ and $\mathrm{CH}_{4}$ emissions on commercial broiler houses under Portuguese winter conditions. The study was made on a commercial broiler farm located in central Portugal. Three tunnel ventilated broiler houses with similar equipment and production practices were selected. The outdoor and indoor environmental conditions, gas concentrations and ventilation rates of each broiler house were measured during 42 days of growing cycle. Results showed that the maximum concentrations of $\mathrm{NH}_{3}, \mathrm{~N}_{2} \mathrm{O}, \mathrm{CO}_{2}$ and $\mathrm{CH}_{4}$ did not exceed the threshold values recommended to maintain indoor air quality on broiler houses. The average emission rates from broiler houses under winter conditions were $0.13 \pm 0.04,0.041 \pm 0.002,96.2 \pm 8.8$ and $0.226 \pm 0.013 \mathrm{~g} \mathrm{day}^{-1}$ bird $^{-1}(22.0 \pm 7.3$, $6.7 \pm 0.3,16,028 \pm 1465$ and $37.7 \pm 2.1 \mathrm{~g} \mathrm{day}^{-1} \mathrm{LU}^{-1}$ ) for $\mathrm{NH}_{3}, \mathrm{~N}_{2} \mathrm{O}, \mathrm{CO}_{2}$ and $\mathrm{CH}_{4}$, respectively. Furthermore, $\mathrm{NH}_{3}$ and $\mathrm{N}_{2} \mathrm{O}$ emission rates of this study are in the same range than measurements from most European countries, but $\mathrm{CH}_{4}$ emission rate seems higher to those reported for Mediterranean countries.
\end{abstract}

(C) 2017 Turkish National Committee for Air Pollution Research and Control. Production and hosting by Elsevier B.V. All rights reserved.

\section{Introduction}

The broiler production in Portugal accounted about 17.1 million places and 253,238 t of meat for consumption in 2015 and ca. 3.5\% of total production in the European Union (INE, 2016; PIIR, 2017). Portugal has about 3\% of chicken meat surplus and this sector represents ca. $12.5 \%$ of animal production. The National poultry production is a very specialized sector with a few number of integrator companies mainly located in the centre of Portugal, and a rearing cycle between 35 and 42 days (2.0-2.4 kg liveweight). Feeding and management techniques are usually provided by the integrator company. The intensive broiler farms have modern mechanically ventilated buildings, equipped with heating and cooling pad systems, and the litter material (rice hulls or wood

\footnotetext{
* Polytechnic Institute of Viseu, Agrarian School of Viseu, CI\&DETS, Quinta da Alagoa, 3500-606 Viseu, Portugal.

E-mail address: jlpereira@esav.ipv.pt.

Peer review under responsibility of Turkish National Committee for Air Pollution Research and Control.
}

shavings) is always removed at the end of the cycle. Regarding the National legislation (REAP, 2013), in each farm, is mandatory an environmental licence and inclusion of the best available techniques for manure management.

Broiler husbandry is a significant source of ammonia $\left(\mathrm{NH}_{3}\right)$, nitrous oxide $\left(\mathrm{N}_{2} \mathrm{O}\right)$, carbon dioxide $\left(\mathrm{CO}_{2}\right)$ and methane $\left(\mathrm{CH}_{4}\right)$ emissions but scarce data are available for Mediterranean conditions. The $\mathrm{NH}_{3}$ emissions from the poultry production were $14.2 \%$ of the total $\mathrm{NH}_{3}$ emissions reported in the Portuguese inventory in 2015 (PIIR, 2017). Acidifying pollutant depositions such as $\mathrm{NH}_{3}$ has a number of negative effects on ecosystems and degradation of materials and existing facilities. Nitrous oxide, $\mathrm{CO}_{2}$ and $\mathrm{CH}_{4}$ are greenhouse gases that contribute to increase greenhouse effect (Pereira et al., 2012; Van der Heyden et al., 2015; Xu et al., 2014; Mostafa et al., 2016).

Gases such as $\mathrm{NH}_{3}, \mathrm{~N}_{2} \mathrm{O}, \mathrm{CO}_{2}$ and $\mathrm{CH}_{4}$ are produced by transformation processes in the excreta/bedding mixture (Méda et al., 2015). The production and emission of gases are a result of complex biological, physical and chemical processes. Broiler excretions are rich in uric acid, being decomposed into urea through aerobic 
decomposition and followed by $\mathrm{NH}_{3}$ and $\mathrm{CO}_{2}$ volatilisation thorough urease enzyme (Rotz, 2004). Nitrous oxide emission is originated by nitrification and denitrification processes whereas $\mathrm{CH}_{4}$ emission coming from anaerobic decomposition of litter materials (Sommer et al., 2006; Pereira et al., 2012). Thus, factors such as ventilation rate, temperature and humidity, litter type, stoking density and management affect the gas concentration and emission from broiler houses (Méda et al., 2015).

Previous studies reported (Calvet et al., 2011; Brouček and Čermák, 2015; Eugene et al., 2015) a great variation on gas emission rates between seasons and countries, being related with outdoor climate, housing and diet supplied to broilers. Hence, more studies are needed, mainly in warmer regions because a very limited number of studies have been conducted under these conditions. Portugal lacks information concerning the broiler sector characterization. There is no information on the gas emission rates related to broiler houses. The aim of this study was to evaluate the $\mathrm{NH}_{3}, \mathrm{~N}_{2} \mathrm{O}, \mathrm{CO}_{2}$ and $\mathrm{CH}_{4}$ emissions on commercial broiler houses under Portuguese winter conditions.

\section{Material and methods}

\subsection{Broiler housing and management}

The study was made on the commercial broiler farm located in central Portugal (Oliveira de Frades, Portugal). Three tunnel ventilated broiler houses (length $=100 \mathrm{~m}$, width $=11 \mathrm{~m}$, ridge $=4.0 \mathrm{~m}$ and sidewall height $=2.7 \mathrm{~m}$ ) with similar equipment and production practices were selected. The broiler houses are a steel construction (year 2013) with insulation (polyurethane) in roof and walls, being oriented East to West (long axis $=100 \mathrm{~m}$ ). Each broiler house had box air inlets (height $=0.38 \mathrm{~m}$ and width $=0.86 \mathrm{~m}$ ) along the sidewalls facing East (height $=0.8 \mathrm{~m}$ and width $=18.0 \mathrm{~m}$ ) and exhaust fans facing West (minimum ventilation $=2178 \mathrm{~m}^{3} \mathrm{~h}^{-1}$ at differential pressure $=0 \mathrm{~Pa}$, maximum ventilation $=$ $365,531 \mathrm{~m}^{3} \mathrm{~h}^{-1}$ at differential pressure $=50 \mathrm{~Pa}$ ), set up within a tunnel ventilation system (Fancom, The Netherlands).

A biomass-fired boiler (model CVT1000S, Ventil, Portugal) was used to heat the houses of whole broiler farm. The water heated on the boiler was then pumped to the inside of each house and sensible heat was released. The ventilation rate was controlled by a control system (model F37, Fancom, The Netherlands) equipped with one sensor of differential pressure (0-100 Pa, Fancom, The Netherlands), two sensors of temperature (model SF7 Fancom, The Netherlands) and two sensors of relative humidity (model RHM.17 for inside and model RHO.17 for outside, Fancom, The Netherlands) placed indoor and outdoor the broiler house.

The experiment started with 10,500 male and 10,500 female broiler chicks per house on day 0 of the production cycle (18-122015) and finished on day 42, with a liveweight of $2.4 \mathrm{~kg} \mathrm{bird}^{-1}$. New bedding material made with rice hulls $\left(3-5 \mathrm{~kg} \mathrm{~m}^{-2}\right.$ ) was used during the experiment. The mortality during the growing cycle was $3.28 \%$ and 8000 broilers per house $\left(1.0 \mathrm{~kg} \mathrm{bird}^{-1}\right)$ were removed on day 27. Birds had ad libitum consumption of feed and water under lighting a period of 20:4 (light:dark) h day ${ }^{-1}$ and a luminance of 20 Lux. Fed was supplied by an automatic feeding system for broilers in line (model Minimax, Roxell, Belgium) with 66 birds per pan, and water was provided by a nipple drinking system (model SPARKnipple, Roxell, Belgium) with 14 birds per drinker. The mean composition (mean \pm standard deviation) of the standards diets provided by the integrator was the following: $88.1 \pm 0.2 \%$ dry matter, $19.2 \pm 2.0 \%$ crude protein, $4.7 \pm 0.5 \%$ crude fat, $2.8 \pm 0.1 \%$ crude fibre and $95.2 \pm 0.6 \%$ organic matter.

\subsection{Gas monitoring and data analysis}

The gas concentrations of each broiler house were measured intermittently on days $1,4,10,12,18,23,26,28,32,35$ and 40 of growing cycle by using a photoacoustic field gas-monitor (model INNOVA 1412i-5, Lumasense Technologies, Denmark) with detection limits of $152.1,58.9,286.4$ and $2947.1 \mu \mathrm{g} \mathrm{m}^{-3}$ for $\mathrm{NH}_{3}, \mathrm{~N}_{2} \mathrm{O}, \mathrm{CO}_{2}$ and $\mathrm{CH}_{4}$, respectively. At each measurement date and at four different times ( $8 \mathrm{~h}, 11 \mathrm{~h}, 14 \mathrm{~h}$ and $18 \mathrm{~h}$ ), were collected individual air samples from the inlet (e.g., from air inlets), middle and outlet (e.g., from exhaust fans) of each broiler house by using an using a field sampling pump (model EW 79200-10, Cole Parmer, USA) to pump a sample of $1.5 \mathrm{~L}$ to a gas sampling bag (Tedlar bag, Cole Parmer, USA). The Tedlar bags were stored in plastic boxes under dark and analyzed up to $24 \mathrm{~h}$ after sampling.

At each gas sampling campaign, data on ventilation rate, indoor temperature and relative humidity were recorded from the climate controller (model F37, Fancom, The Netherlands) of each broiler house. The outdoor temperature and relative humidity were recorded every $10 \mathrm{~min}$ over the growing cycle using a sensor (model CS215, Campbell Scientific, UK) connected to a micrologger (model CR3000, Campbell Scientific, UK).

The emissions of $\mathrm{NH}_{3}, \mathrm{~N}_{2} \mathrm{O}, \mathrm{CO}_{2}$ and $\mathrm{CH}_{4}$ of each broiler house were estimated by a mass balance (Calvet et al., 2011; Alberdi et al., 2016) according Eq. (1).

$\mathrm{ER}=\mathrm{VR} \times\left(\mathrm{C}_{\text {inlet }}-\mathrm{C}_{\text {outlet }}\right)$

where, ER was the gas $\left(\mathrm{NH}_{3}, \mathrm{~N}_{2} \mathrm{O}, \mathrm{CO}_{2}\right.$ or $\left.\mathrm{CH}_{4}\right)$ emission $\left(\mathrm{mg} \mathrm{h}^{-1}\right)$, VR was the ventilation rate in the broiler house $\left(\mathrm{m}^{3} \mathrm{~h}^{-1}\right)$, and $\mathrm{C}_{\text {inlet }}$ and $\mathrm{C}_{\text {outlet }}$ were the outlet and inlet gas $\left(\mathrm{NH}_{3}, \mathrm{~N}_{2} \mathrm{O}, \mathrm{CO}_{2}\right.$ or $\mathrm{CH}_{4}$ ) concentrations measured in inlet and outlet air, respectively $\left(\mathrm{mg} \mathrm{m}^{-3}\right)$.

The daily mortality rates as well as the removal of the 8000 broilers were recorded and accounted in the calculation of the average emission rates. The daily estimates of gas emission rates $\left(\mathrm{g} \mathrm{day}^{-1}\right.$ bird $^{-1}$ ) were determinate considering the mean values of the four sampling times of each day $(8 \mathrm{~h}, 11 \mathrm{~h}, 14 \mathrm{~h}$ and $18 \mathrm{~h})$. The cumulative gas emissions were determinate considering the mean gas emission rates and the time interval between two sequential dates of growing cycle. Broiler numbers were expressed in livestock unit (LU), considering that one broiler was 0.006 LU (REAP, 2013).

Data were subjected to one-way analysis of variance and Tukey comparisons of means tests $(p<0.05)$ were carried out using the statistical software package Statistix 7.0 (USA).

\section{Results and discussion}

\subsection{Environmental conditions}

The outdoor and indoor air temperature and relative humidity as well as the ventilation rates from each broiler house are shown in Fig. $1 \mathrm{~A}-\mathrm{C}$ and Table 1 . During the growing cycle, the outdoor average temperatures ranged from 2.5 to $18.5^{\circ} \mathrm{C}$ and the average relative humidity varied between 34.2 and $100 \%$ (Fig. 1A-B). Thus, there were significant $(p<0.05)$ on a few days (for indoor temperature) and for a larger period (for indoor relative humidity) between the three broiler houses, being observed an increase of the temperature and a decrease of the relative humidity from day 0 to day 42 (Fig. 1A-B). Hence, during the growing cycle, the indoor average temperatures varied from 31.6 to $20.6{ }^{\circ} \mathrm{C}$ while indoor average relative humidity ranged from 30.8 to $69.4 \%$ (Fig. 1A-B). The high values of indoor temperature and low values of indoor relative humidity relative to outdoor climatic conditions (Table 1 ) 

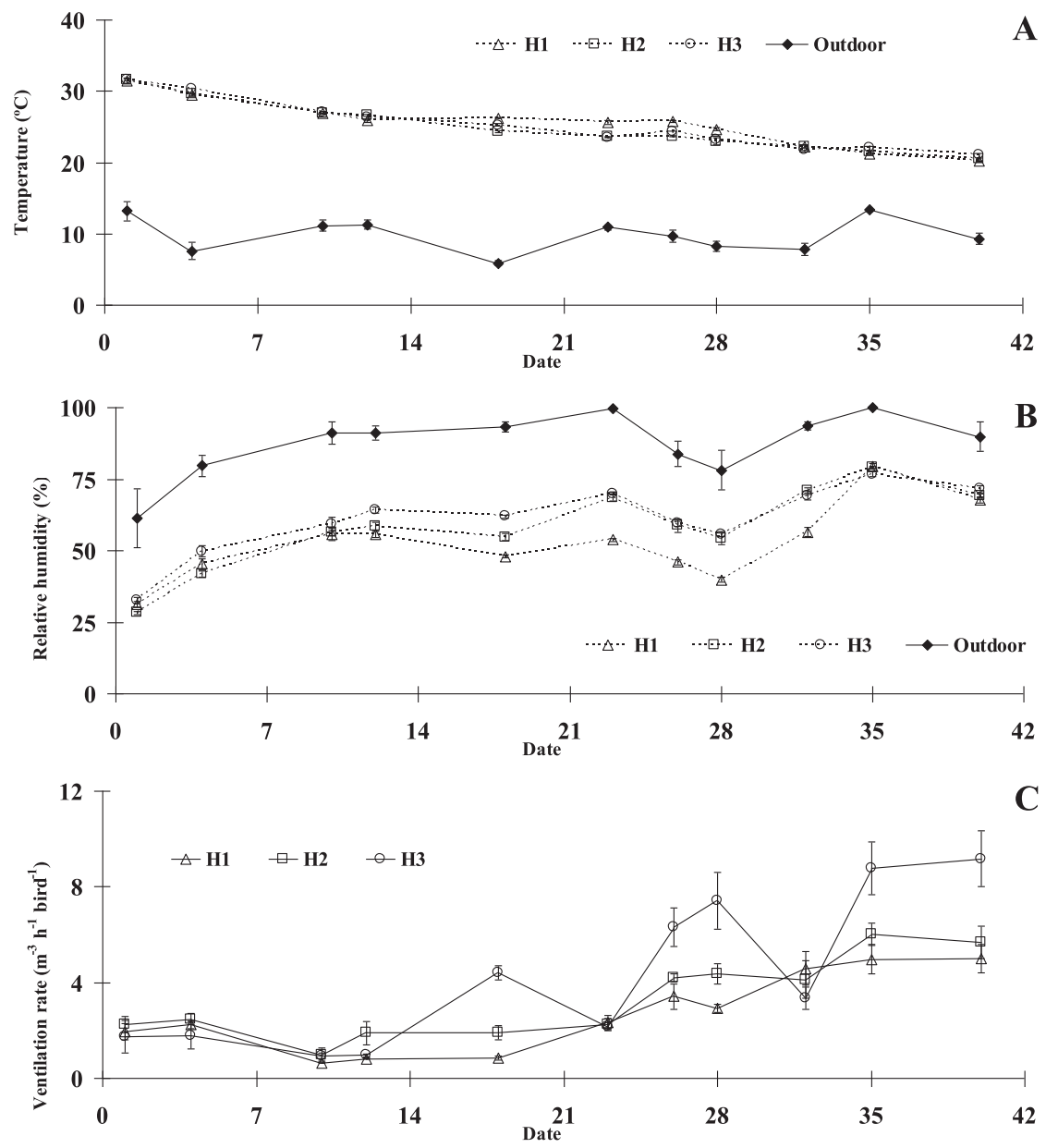

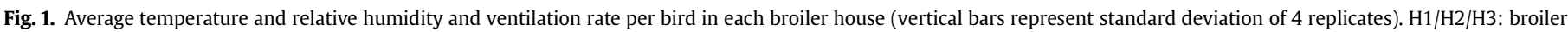
houses. Outdoor: ambient air temperature and relative humidity.

Table 1

Average climatic conditions, gas concentrations and cumulative emissions (mean \pm standard deviation) in each broiler house.

\begin{tabular}{|c|c|c|c|}
\hline \multirow[t]{2}{*}{ Parameters } & \multicolumn{3}{|l|}{ Broiler houses } \\
\hline & $\mathrm{H} 1$ & $\mathrm{H} 2$ & H3 \\
\hline \multicolumn{4}{|l|}{ Climatic conditions } \\
\hline Outdoor temperature $\left({ }^{\circ} \mathrm{C}\right)$ & $9.9 \pm 2.7$ & & \\
\hline Indoor temperature $\left({ }^{\circ} \mathrm{C}\right)$ & $25.4 \pm 3.3^{\mathrm{a}}$ & $24.9 \pm 3.5^{\mathrm{b}}$ & $25.1 \pm 3.4^{\mathrm{ab}}$ \\
\hline Outdoor relative humidity (\%) & $88.7 \pm 12.8$ & & \\
\hline Indoor relative humidity (\%) & $52.7 \pm 13.1^{\mathrm{c}}$ & $58.2 \pm 14.2^{\mathrm{b}}$ & $61.0 \pm 12.2^{\mathrm{a}}$ \\
\hline Ventilation rate $\left(\mathrm{m}^{3} \mathrm{~h}^{-1}\right.$ bird $\left.^{-1}\right)$ & $2.7 \pm 1.6^{\mathrm{b}}$ & $3.3 \pm 1.7^{b}$ & $4.3 \pm 3.1^{\mathrm{a}}$ \\
\hline \multicolumn{4}{|l|}{ Gas concentrations } \\
\hline $\mathrm{NH}_{3}\left(\mathrm{mg} \mathrm{m}^{-3}\right)$ & $0.8 \pm 0.6^{\mathrm{a}}$ & $1.2 \pm 1.2^{\mathrm{a}}$ & $1.4 \pm 1.1^{\mathrm{a}}$ \\
\hline $\mathrm{N}_{2} \mathrm{O}\left(\mathrm{mg} \mathrm{m}^{-3}\right)$ & $1.2 \pm 0.2^{\mathrm{a}}$ & $1.1 \pm 0.2^{\mathrm{b}}$ & $1.0 \pm 0.1^{\mathrm{b}}$ \\
\hline $\mathrm{CO}_{2}\left(\mathrm{mg} \mathrm{m}^{-3}\right)$ & $1284 \pm 341^{\mathrm{a}}$ & $1674 \pm 558^{\mathrm{a}}$ & $1834 \pm 524^{\mathrm{a}}$ \\
\hline $\mathrm{CH}_{4}\left(\mathrm{mg} \mathrm{m}^{-3}\right)$ & $3.8 \pm 1.1^{\mathrm{a}}$ & $3.4 \pm 0.9^{\mathrm{a}}$ & $3.9 \pm 1.2^{\mathrm{a}}$ \\
\hline \multicolumn{4}{|l|}{ Gas emissions } \\
\hline $\mathrm{NH}_{3}\left(\mathrm{~g} \mathrm{bird}^{-1}\right)$ & $3.01 \pm 0.99^{\mathrm{b}}$ & $6.05 \pm 1.18^{\mathrm{ab}}$ & $7.59 \pm 3.65^{\mathrm{a}}$ \\
\hline $\mathrm{NH}_{3}\left(\right.$ g day $^{-1}$ bird $\left.^{-1}\right)$ & $0.072 \pm 0.024^{\mathrm{b}}$ & $0.144 \pm 0.003^{\mathrm{ab}}$ & $0.181 \pm 0.087^{\mathrm{a}}$ \\
\hline $\mathrm{NH}_{3}\left(\mathrm{~g} \mathrm{day}^{-1} \mathrm{LU}^{-1}\right)$ & $11.9 \pm 3.9^{\mathrm{b}}$ & $24.0 \pm 0.5^{\mathrm{ab}}$ & $30.1 \pm 14.5^{\mathrm{a}}$ \\
\hline $\mathrm{N}_{2} \mathrm{O}\left(\mathrm{g} \mathrm{bird}^{-1}\right)$ & $1.73 \pm 0.29^{\mathrm{a}}$ & $1.62 \pm 0.14^{\mathrm{a}}$ & $1.76 \pm 0.19^{\mathrm{a}}$ \\
\hline $\mathrm{N}_{2} \mathrm{O}\left(\mathrm{g} \mathrm{day}^{-1}\right.$ bird $\left.^{-1}\right)$ & $0.041 \pm 0.007^{\mathrm{a}}$ & $0.039 \pm 0.003^{\mathrm{a}}$ & $0.042 \pm 0.005^{\mathrm{a}}$ \\
\hline $\mathrm{N}_{2} \mathrm{O}\left(\mathrm{g}_{\text {day }^{-1}} \mathrm{LU}^{-1}\right)$ & $6.8 \pm 1.2^{\mathrm{a}}$ & $6.4 \pm 0.6^{\mathrm{a}}$ & $7.0 \pm 0.8^{\mathrm{a}}$ \\
\hline $\mathrm{CO}_{2}\left(\mathrm{~g} \mathrm{bird}^{-1}\right)$ & $2544 \pm 1264^{b}$ & $4412 \pm 1133^{\mathrm{ab}}$ & $5161 \pm 1828^{a}$ \\
\hline $\mathrm{CO}_{2}\left(\mathrm{~g} \mathrm{day}^{-1}\right.$ bird $\left.^{-1}\right)$ & $60.6 \pm 30.1^{\mathrm{b}}$ & $105.0 \pm 27.0^{\mathrm{ab}}$ & $122.9 \pm 43.5^{\mathrm{a}}$ \\
\hline $\mathrm{CO}_{2}\left(\mathrm{~g} \mathrm{day}^{-1} \mathrm{LU}^{-1}\right)$ & $10,095 \pm 5016^{\mathrm{b}}$ & $17,508 \pm 4496^{\mathrm{ab}}$ & $20,480 \pm 7254^{\mathrm{a}}$ \\
\hline $\mathrm{CH}_{4}\left(\mathrm{~g} \mathrm{bird}^{-1}\right)$ & $7.79 \pm 1.00^{\mathrm{b}}$ & $8.02 \pm 0.17^{b}$ & $12.67 \pm 1.14^{\mathrm{a}}$ \\
\hline $\mathrm{CH}_{4}\left(\mathrm{~g} \mathrm{day}^{-1}\right.$ bird $\left.^{-1}\right)$ & $0.185 \pm 0.024^{b}$ & $0.191 \pm 0.004^{\mathrm{b}}$ & $0.302 \pm 0.027^{\mathrm{a}}$ \\
\hline $\mathrm{CH}_{4}\left(\mathrm{~g} \mathrm{day}^{-1} \mathrm{LU}^{-1}\right)$ & $30.9 \pm 3.9^{\mathrm{b}}$ & $31.8 \pm 0.7^{\mathrm{b}}$ & $50.3 \pm 4.5^{\mathrm{a}}$ \\
\hline
\end{tabular}

Values presented with different superscripts within rows are significantly different $(p<005)$ according to the Tukey test.

One broiler ( $2.4 \mathrm{~kg}$ liveweight and 42 days age $)=0.006 \mathrm{LU}$ (livestock unit). 
are related with the heating system by boiler that introduces sensible heat in the broiler houses, decreasing the indoor relative humidity.

The ventilation rates increased significantly $(p<0.05)$ during the 42 days of experiment in all broiler houses, with average values that ranged from 2.0 to $6.6 \mathrm{~m}^{3} \mathrm{~h}^{-1}$ bird $^{-1}$ (Fig. 1C and Table 1). Results are in agreement with previous studies (Seedorf et al., 1998; Calvet et al., 2011) who reported that the ventilation rates increased with bird age and ranged between 1.8 and $4.9 \mathrm{~m}^{3} \mathrm{~h}^{-1}$ bird $^{-1}$ in winter. However, the ventilation rates in broiler house $\mathrm{H} 3$ were higher than broiler houses $\mathrm{H} 1$ and $\mathrm{H} 2$ (Table 1). The higher ventilation rates in broiler house $\mathrm{H} 3$ were especially hard to justify since the commercial scale research is very difficult to assess.

The concentrations of $\mathrm{NH}_{3}, \mathrm{~N}_{2} \mathrm{O}, \mathrm{CO}_{2}$ and $\mathrm{CH}_{4}$ increased during the growing cycle, but maximum concentrations did not exceed 4.0,
1.5, 3000 and $7.0 \mathrm{mg} \mathrm{m}^{-3}$, respectively (Fig. 2A-D and Table 1). Thus, the maximum concentrations of $\mathrm{NH}_{3}$ and $\mathrm{CO}_{2}$ did not exceed the threshold values of 15.2 and $5894.2 \mathrm{mg} \mathrm{m}^{-3}$, respectively, as recommended by CIGR (1992) to maintain a good indoor air quality on broiler houses.

\subsection{Ammonia emissions}

The gas emission rates from broiler houses are presented in Fig. 3 and Table 1 . The $\mathrm{NH}_{3}$ emissions from the broiler houses were lower than $0.18 \mathrm{~g} \mathrm{day}^{-1}$ bird $^{-1}$ throughout the first 28 days of growing cycle, followed by an increase $\left(0.18-0.70 \mathrm{~g} \mathrm{NH}_{3} \mathrm{day}^{-1}\right.$ bird $^{-1}$ ) until the end of the growing cycle (Fig. 3A). The cumulative $\mathrm{NH}_{3}$ emission in the broiler house $\mathrm{H} 3$ was higher (numerically but not statistically) relative to all other broiler houses, with average
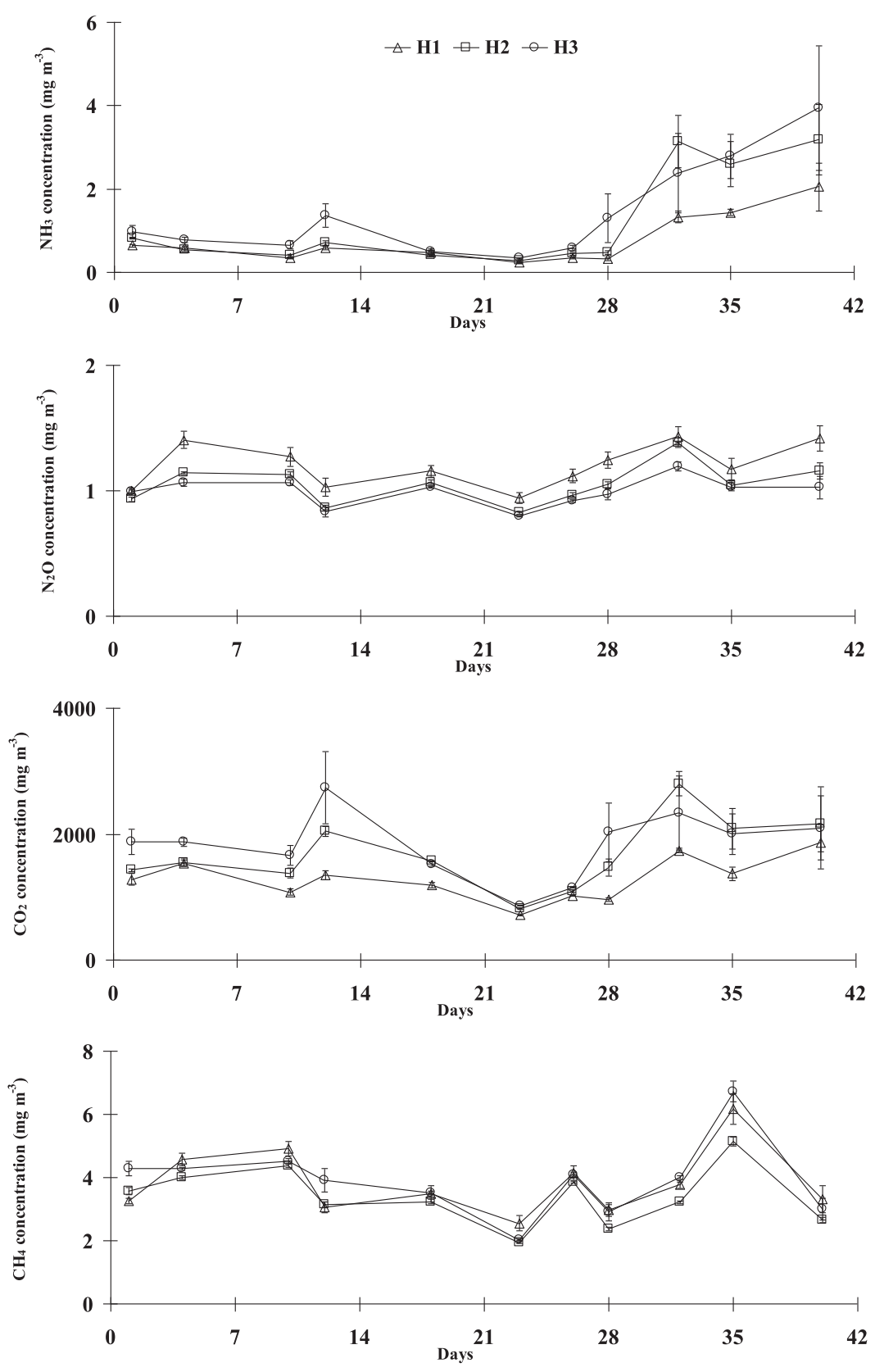

Fig. 2. Ammonia and greenhouse gas concentration in the broiler houses (vertical bars represent standard deviation of 4 replicates). H1, H2, H3: broiler houses. 
$\mathrm{NH}_{3}$ emission rates that ranged from 0.07 to $0.18 \mathrm{~g} \mathrm{day}^{-1}$ bird $^{-1}$ (11.9-30.1 $\mathrm{g} \mathrm{NH}_{3} \mathrm{day}^{-1} \mathrm{LU}^{-1}$ ) for all three broiler houses (Table 1). Results of this study follow the same trend reported for Mediterranean conditions, by Guiziou and Béline (2005) and Calvet et al. (2011) who found a great increase in $\mathrm{NH}_{3}$ emissions on day 28 during winter. Excluding differences between management practices, the higher $\mathrm{NH}_{3}$ emission rates obtained in the present study to those reported by Calvet et al. (2011) could be related with environmental factors and diets such as the high ventilation rate observed in the referred study $\left(4.9 \mathrm{~m}^{3} \mathrm{~h}^{-1}\right.$ bird $^{-1}$ in Spain against $3.4 \mathrm{~m}^{3} \mathrm{~h}^{-1}$ bird $^{-1}$ in Portugal).

Table 2 shows published data of gas emission rates from broiler houses provided with new litter in each growing cycle and during winter conditions. The $\mathrm{NH}_{3}$ emission rates for broilers varied from 0.09 to $0.43 \mathrm{~g} \mathrm{day}^{-1}$ bird $^{-1}$ in European countries (Table 2). The average $\mathrm{NH}_{3}$ emission rate obtained in the present study $(0.13 \mathrm{~g}$ $\mathrm{NH}_{3}$ day $^{-1}$ bird $^{-1}$ ) was comparable with values reported by Nicholson et al. (2004) in UK and Guiziou and Béline (2005) in France $\left(0.12-0.16 \mathrm{~g} \mathrm{NH}_{3}\right.$ day $^{-1}$ bird $\left.^{-1}\right)$, but lower than emission rate measured by Hayes et al. (2006) in Ireland and Calvet et al. (2011) in Spain $\left(0.35-0.43 \mathrm{~g} \mathrm{NH}_{3}\right.$ day $^{-1}$ bird $\left.^{-1}\right)$. Hence, we conclude that the $\mathrm{NH}_{3}$ emission rate of this study was in the same range than values measured $\left(0.09-0.16 \mathrm{~g} \mathrm{NH}_{3}\right.$ day $^{-1}$ bird $\left.^{-1}\right)$ in most European countries.

\subsection{Greenhouse gas emissions}

No significant differences $(p>0.05)$ were observed between broiler houses in terms of $\mathrm{N}_{2} \mathrm{O}$ emissions, being observed a progressive increase on emissions $\left(0.019-0.084 \mathrm{~g} \mathrm{~N}_{2} \mathrm{O}\right.$ day $^{-1}$ bird $^{-1}$ )

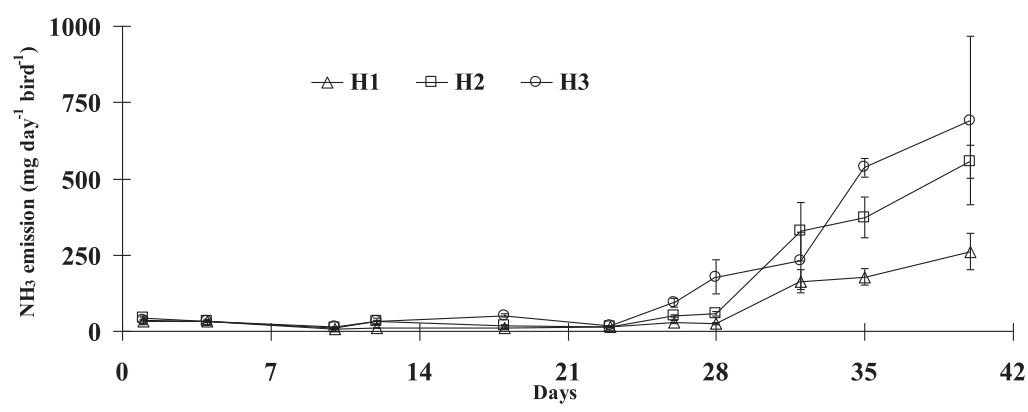

A
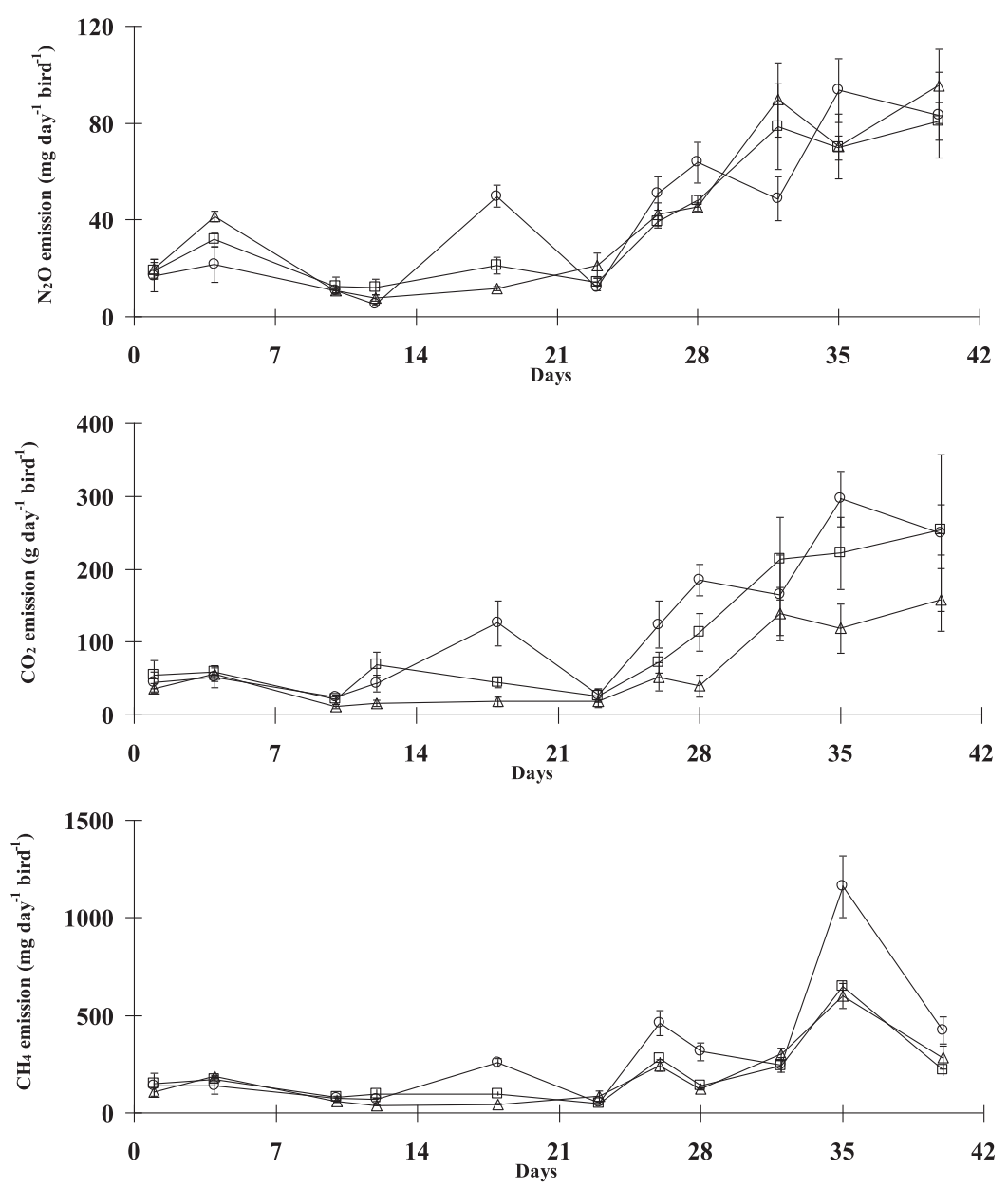

C

D

Fig. 3. Ammonia and greenhouse gas emission per bird from each broiler house (vertical bars represent standard deviation of 4 replicates). H1, H2, H3: broiler houses. 
Table 2

Ammonia, $\mathrm{N}_{2} \mathrm{O}$ and $\mathrm{CH}_{4}$ emissions from broiler houses with new litter after each flock and during winter.

\begin{tabular}{|c|c|c|c|c|c|}
\hline \multirow[t]{2}{*}{ Country } & \multirow[t]{2}{*}{ Reference } & \multirow[t]{2}{*}{ Cycle duration (days) } & \multicolumn{3}{|c|}{ Gas emissions ( $\mathrm{g} \mathrm{day}^{-1}$ bird $^{-1}$ ) } \\
\hline & & & $\mathrm{NH}_{3}$ & $\mathrm{~N}_{2} \mathrm{O}$ & $\mathrm{CH}_{4}$ \\
\hline Canada & Roumeliotis et al. (2010) & 34 & 0.18 & & 0.753 \\
\hline Australia & Wiedemann et al. (2016) & 42 & 0.28 & 0.007 & 0.004 \\
\hline USA & Eugene et al. (2015) & 42 & 0.48 & 0.049 & 0.414 \\
\hline USA & Wheeler et al. (2008) & 42 & 0.47 & & \\
\hline USA & Gates et al. (2008) & 40 & 0.40 & & \\
\hline Portugal & This study & 42 & 0.13 & 0.041 & 0.226 \\
\hline Spain & Calvet et al. (2011) & 48 & 0.43 & 0.051 & 0.045 \\
\hline France & Guiziou and Béline (2005) & 35 & 0.16 & 0 & 0 \\
\hline Italy & da Borso and Chiumenti (1999) & & 0.40 & & \\
\hline Ireland & Hayes et al. (2006) & 35 & 0.35 & & \\
\hline UK & Nicholson et al. (2004) & 46 & 0.12 & & \\
\hline Germany & Müller et al. (2003) & 32 & 0.09 & & \\
\hline Slovakia & Knížatová et al. (2010) & 40 & 0.16 & & \\
\hline
\end{tabular}

during the growing cycle (Fig. 3B). No differences $(p>0.05)$ in the cumulative $\mathrm{N}_{2} \mathrm{O}$ emissions were observed between broiler houses, with an average $\mathrm{N}_{2} \mathrm{O}$ emission rate of $0.041 \pm 0.002 \mathrm{~g} \mathrm{day}^{-1}$ bird $^{-1}$ $\left(6.7 \pm 0.3 \mathrm{~g} \mathrm{~N}_{2} \mathrm{O} \mathrm{day}{ }^{-1} \mathrm{LU}^{-1}\right)$ for all three broiler houses (Table 1$)$. The $\mathrm{N}_{2} \mathrm{O}$ emission rate obtained in this study $\left(0.041 \mathrm{~g} \mathrm{~N}_{2} \mathrm{O}\right.$ day $^{-1}$ bird $^{-1}$ ) is comparable to those reported by Eugene et al. (2015) in USA and by Calvet et al. (2011) in Spain (0.049-0.051 $\mathrm{g} \mathrm{N}_{2} \mathrm{O}$ day $^{-1}$ bird $^{-1}$ ), but much larger than those reported by Guiziou and Béline (2005) in France and by Wiedemann et al. (2016) in Australia (0-0.007 $\mathrm{g} \mathrm{N}_{2} \mathrm{O}$ day $^{-1}$ bird $^{-1}$ ) (Table 2).

In all broiler houses, the emissions of $\mathrm{CO}_{2}$ were lower than $120 \mathrm{~g}$ day $^{-1}$ bird $^{-1}$ during the first 28 days of growing cycle (Fig. 3C). Up this day until the end of the growing cycle, the $\mathrm{CO}_{2}$ emissions increased quickly $\left(120-300 \mathrm{~g} \mathrm{CO}_{2}\right.$ day $^{-1}$ bird $\left.^{-1}\right)$ in all broiler houses (Fig. $3 \mathrm{C}$ ). The cumulative $\mathrm{CO}_{2}$ emission from broiler house $\mathrm{H} 3$ was higher (numerically but not statistically) relative to broiler houses $\mathrm{H} 1$ and $\mathrm{H} 2$, with $\mathrm{CO}_{2}$ emission rates that ranged from 60.6 to $122.9 \mathrm{~g} \mathrm{day}^{-1}$ bird $^{-1}\left(10.1-20.4 \mathrm{~kg} \mathrm{CO}_{2}\right.$ day $\left.^{-1} \mathrm{LU}^{-1}\right)$ in all broiler houses (Table 1 ). Results are in agreement with previous studies (CIGR, 2002; Calvet et al., 2011) who reported an average $\mathrm{CO}_{2}$ emission rate between 91.2 and $98.4 \mathrm{~g} \mathrm{day}^{-1}$ bird $^{-1}$ in European broiler houses.

The emissions of $\mathrm{CH}_{4}$ in broiler houses $\mathrm{H} 1$ and $\mathrm{H} 2$ increase slowly, but were lower than $0.672 \mathrm{~g} \mathrm{day}^{-1}$ bird $^{-1}$ throughout the 42 days of growing cycle (Fig. 3D). From day 23 until the end of the growing cycle, $\mathrm{CH}_{4}$ emission in broiler house $\mathrm{H} 3$ was significantly higher $(p<0.05)$ than in broiler houses $\mathrm{H} 1$ and $\mathrm{H} 2$ (Fig. 3D). The cumulative $\mathrm{CH}_{4}$ emission from broiler house $\mathrm{H} 3$ was significantly higher $(p<0.05)$ relative to houses $\mathrm{H} 1$ and $\mathrm{H} 2$, with average $\mathrm{CH}_{4}$ emission rates that varied between 0.185 and $0.302 \mathrm{~g} \mathrm{day}^{-1}$ bird $^{-1}\left(30.9 \pm 3.9\right.$ to $50.3 \pm 4.5 \mathrm{~g} \mathrm{CH}_{4}$ day $\left.^{-1} \mathrm{LU}^{-1}\right)$ in the three broiler houses (Table 1). The amount of litter material ranged from 3 to $5 \mathrm{~kg} \mathrm{~m}^{-2}$ because, during the growing cycle, extra amounts of bedding material have been added every week. Thus, the broiler house H3 have received a higher amount of bedding material relative to the other two broiler houses, which may explain the higher $\mathrm{CO}_{2}$ and $\mathrm{CH}_{4}$ emissions (Fig. $3 \mathrm{C}-\mathrm{D}$ and Table 1).

As can be observed in Table 2, the $\mathrm{CH}_{4}$ emission rates for broilers varied greatly between countries $\left(0-0.753 \mathrm{~g} \mathrm{CH}_{4} \mathrm{day}^{-1}\right.$ bird $\left.{ }^{-1}\right)$. The $\mathrm{CH}_{4}$ emission rate $\left(0.226 \mathrm{~g} \mathrm{CH}_{4}\right.$ day $^{-1}$ bird $\left.^{-1}\right)$ was lower than values measured by Eugene et al. (2015) in USA and Roumeliotis et al. (2010) in Canada (0.414-0.753 $\mathrm{g} \mathrm{CH}_{4} \mathrm{day}^{-1}$ bird $^{-1}$ ) and higher than emission rate reported by Calvet et al. (2011) in Spain and by Guiziou and Béline (2005) in France $\left(0-0.045 \mathrm{~g} \mathrm{CH}_{4}\right.$ day $^{-1}$ bird $\left.^{-1}\right)$. Thus, the $\mathrm{CH}_{4}$ emission rate of this study was higher to those reported in other European countries as well as the IPCC emission factor (IPCC, 2006) for Mediterranean countries $\left(0.050 \mathrm{~g} \mathrm{CH}_{4}\right.$ day $^{-1}$ bird $\left.^{-1}\right)$.

\section{Conclusions}

The maximum concentrations of $\mathrm{NH}_{3}, \mathrm{~N}_{2} \mathrm{O}, \mathrm{CO}_{2}$ and $\mathrm{CH}_{4}$ did not exceed the threshold values recommended to maintain indoor air quality on broiler houses. The average emission rates from commercial broiler houses under Mediterranean winter conditions were $0.13 \pm 0.04,0.041 \pm 0.002,96.2 \pm 8.8$ and $0.226 \pm 0.013 \mathrm{~g}$ day $^{-1}$ bird $^{-1}(22.0 \pm 7.3,6.7 \pm 0.3,16,028 \pm 1465$ and $37.7 \pm 2.1 \mathrm{~g}$ day ${ }^{-1} \mathrm{LU}^{-1}$ ) for $\mathrm{NH}_{3}, \mathrm{~N}_{2} \mathrm{O}, \mathrm{CO}_{2}$ and $\mathrm{CH}_{4}$, respectively. Furthermore, $\mathrm{NH}_{3}$ and $\mathrm{N}_{2} \mathrm{O}$ emission rates of this study are in the same range than measurements from most European countries, but $\mathrm{CH}_{4}$ emission rate seems higher to those reported for Mediterranean countries. The data from this study represent the first direct measurement of gas emissions from broiler houses in Portugal but more studies are needed to fully evaluate gas emission rates during the whole year.

\section{Acknowledgments}

The author acknowledges Pedro Ferreira and João Borges (LUSIAVES) for the facilities and technical data, and Susana Alves (Polytechnic Institute of Viseu) for gas sampling campaigns. This work was supported by European Investment Funds by FEDER/ COMPETE/POCI - Operational Competitiveness and Internationalisation Programme, under project POCI-01-0145-FEDER-006958, project Ovislab ICT-2013-05-004-5314 ID-64757, project POCI-010247-FEDER-003430 AMONIAVE and National Funds by FCT - Portuguese Foundation for Science and Technology, under the project UID/AGR/04033/2013 and Portugal2020.

\section{References}

Alberdi, O., Arriaga, H., Calvet, S., Estellés, F., Merino, P., 2016. Ammonia and greenhouse gas emissions from an enriched cage laying hen facility. Biosyst. Eng. 144, 1-12.

Brouček, J., Čermák, B., 2015. Emission of harmful gases from poultry farms and possibilities of their reduction. Ekol. Bratisl. 34, 89-100.

Calvet, S., Cambra-López, M., Estellés, F., Torres, A.G., 2011. Characterization of gas emissions from a Mediterranean broiler farm. Poult. Sci. 90, 534-542.

CIGR, 1992. Climatization of Animal Houses. Second Report of the Working Group on Climatization of Animal Houses. International Commission of Agricultural Engineering (CIGR), Ghent, Belgium, p. 147.

CIGR, 2002. In: Pedersen, S., Sälvik, K. (Eds.), Climatization of Animal Houses. Heat and Moisture Production at Animal and House Levels. Danish Inst. Agric. Sci., Horsens, Denmark, p. 45.

da Borso, F., Chiumenti, R., 1999. Poultry housing and manure management systems: recent development in Italy as regards ammonia emissions. In: Proceedings of the 8th International Conference of the FAO ESCORENA Network on Recycling of Agricultural, Municipal and Industrial Residues in Agriculture. 
RAMIRAN 98, Rennes, pp. 15-21.

Eugene, B., Moore, P.A., Li, H. Miles, D., Trabue, S., Burns, R., Buser, M., 2015. Effect of alum additions to poultry litter on in-house ammonia and greenhouse gas concentrations and emissions. J. Environ. Qual. 44, 1530-1540.

Gates, R.S., Casey, K.D., Wheeler, E.F., Xin, H., Pescatore, A.J., 2008. US broiler housing ammonia emissions inventory. Atmos. Environ. 42, 3342-3350.

Guiziou, F., Béline, F., 2005. In situ measurement of ammonia and greenhouse gas emissions from broiler houses in France. Bioresour. Technol. 96, 203-207.

Hayes, E.T., Curran, T.P., Dodd, V.A., 2006. Odour and ammonia emissions from intensive poultry units in Ireland. Bioresour. Technol. 97, 933-939.

INE, 2016. Estatísticas Agrícolas 2015. Instituto Nacional de Estatística, I.P., Lisboa, Portugal, p. 166.

IPCC 2006, 2006. IPCC guidelines for national greenhouse gas inventories. In: Eggleston, H.S., Buendia, L., Miwa, K., Ngara, T., Tanabe, K. (Eds.), IPCC National Greenhouse Gas Inventories Programme, Technical Support Unit. IGES, Hayama, Japan. http://www.ipcc-nggip.iges.or.jp.

Knížatová, M., Mihina, Š., Brouček, J., Karandušovská, I., Mačuhová, J., 2010. The influence of litter age, litter temperature and ventilation rate on ammonia emissions from a broiler rearing facility. Czech J. Anim. Sci. 55, 337-345.

Méda, B., Hassouna, M., Lecomte, M., Germain, K., Dourmad, J.-Y., Robin, P., 2015. Influence of season and outdoor run characteristics on excretion behaviour of organic broilers and gaseous emissions. Biosyst. Eng. 139, 35-47.

Mostafa, E., Hoelscher, R., Diekmann, B., Ghaly, A.E, Buescher, W., 2016. Evaluation of two indoor air pollution abatement techniques in forced-ventilation fattening pig barns. Atmos. Pollut. Res. 8, 428-438.

Müller, H.-J., Brunsch, R., Hörnig, G., Jelinek, A., 2003. Odour and ammonia emissions from poultry houses with different keeping and ventilation systems. In: Proceedings of the International Symposium on Gaseous and Odour Emissions from Animal Production Facilities, Horsens, pp. 172-179.

Nicholson, F.A., Chambers, J., Walker, A.W., 2004. Ammonia emissions from broiler litter and laying hen manure management systems. Biosyst. Eng. 89, 175-185.

Pereira, J., Misselbrook, T.H., Chadwick, D.R., Coutinho, J., Trindade, H., 2012. Effects of temperature and dairy cattle excreta characteristics on potential ammonia and greenhouse gas emissions from housing: a laboratory study. Biosyst. Eng. $112,138-150$.
PIIR, 2017. Portuguese Informative Inventory Report 1990-2015. Submitted under the NEC Directive (EU) 2016/2284 and the UNECE Convention on Long-range Transboundary Air Pollution. Portuguese Informative Inventory Report (PIIR). Portuguese Environmental Agency, Lisbon, Portugal, p. 449.

REAP, 2013. Decree number $81 / 2013$ of 14 June regarding animal manure management (REAP). In: Diário da República, Série I, number 113 of 14 June 2013. Portugal, pp. 3304-3329.

Roumeliotis, T.S., Dixon, B.J., Van Heyst, B.J., 2010. Characterization of gaseous pollutant and particulate matter emission rates from a commercial broiler operation. Part I: observed trends in emissions. Atmos. Environ. 44, 3770-3777.

Rotz, C.A., 2004. Management to reduce nitrogen losses in animal production. J. Anim. Sci. 82, E119-E137.

Seedorf, J. Hartung, J. Schröder, M., Linkert, K.H. Pedersen, S., Takai, $H$. Johnsen, J.O., Metz, J.H.M., Groot Koerkamp, P.W.G., Uenk, G.H., Phillips, V.R., Holden, M.R., Sneath, R.W., Short, J.L., White, R.P., Wathes, C.M., 1998. A survey of ventilation rates in livestock buildings in Northern Europe. J. Agric. Eng. Res. 70, 39-47.

Sommer, S.G., Zhang, G.Q., Bannink, A., Chadwick, D., Misselbrook, T., Harrison, R., Hutchings, N.J., Menzi, H., Monteny, G.J., Ni, J.Q., Oenema, O., Webb, J., 2006. Algorithms determining ammonia emission from buildings housing cattle and pigs and from manure stores. Adv. Agron. 89, 261-335.

Van der Heyden, C., Demeyer, C., Volcke, E.I.P., 2015. Mitigating emissions from pig and poultry housing facilities through air scrubbers and biofilters: state-of-theart and perspectives. Biosyst. Eng. 134, 74-93.

Wheeler, E.F., Casey, K.D., Gates, R.S., Xin, H., Zajaczkowski, J.L., Topper, P.A., Liang, Y., Pescatore, A.J., 2008. Ammonia emissions from twelve U.S. broiler chicken houses. Trans. ASABE 49, 1495-1512.

Wiedemann, S.G., Phillips, F.A., Naylor, T.A., McGahan, E.J., Keane, O.B., Warren, B.R., Murphy, C.M., 2016. Nitrous oxide, ammonia and methane from Australian meat chicken houses measured under commercial operating conditions and with mitigation strategies applied. Anim. Prod. Sci. 56, 1404-1417.

Xu, W., Zheng, K., Liu, X., Meng, L., Huaitalla, R.M., Shen, J., Hartung, E., Gallmann, E., Roelcke, M., Zhang, F., 2014. Atmospheric $\mathrm{NH}_{3}$ dynamics at a typical pig farm in China and their implications. Atmos. Pollut. Res. 5, 455-463. 